\title{
SECONDARY SCHOOL TEACHERS' UTILIZATION OF INDIGENOUS INSTRUCTIONAL RESOURCES IN TEACHING BASIC TECHNOLOGY IN KWARA STATE
}

\author{
Aderonke Kofo Soetan, Amosa Ochayi Onojah, \\ Alli Silifat Oluwakemi, Aladesusi Gboyega Ayodeji, \\ Aderogba Adenike Janet, Obielodan Omotayo Olabo
}

\author{
University of Ilorin
}

\begin{abstract}
Indigenous instructional resources are the local or native resources which the teachers use to make abstract lessons more meaningful and understandable. However, lack of instructional resources and inappropriate utilization could contribute to the poor performance of students. Therefore, this study investigated (i) the types of indigenous instructional resources that are available for basic technology (ii) if basic technology teachers use indigenous instructional resources (iii) influence of gender in using indigenous instructional resources by the teacher in a secondary school in Kwara State. The survey method was adopted, and data was collected using a researcher-design questionnaire to gather the necessary information which inference was drawn from. The sample of this study was selected using simple random sampling techniques. 312 respondents. The finding revealed that the available indigenous instructional resources are being utilized by basic technology teachers and there was no significant difference between male and female teacher utilization of indigenous instructional resources for teaching basic technology. The study concluded that indigenous instructional resources are being utilized by basic technology teachers in a secondary school in Kwara State. This implies that lessons taught with the guide of indigenous instructional material arouse learners' interest to understand what is been taught. It was therefore recommended that need to evolve policy actions that will increase access to indigenous instructional resources and actions to improve its quality.
\end{abstract}

Keywords: Utilization, Indigenous Instructional Resources, Basic Technology, Teaching, Learning. 


\section{Background of the study}

Education is the backbone of any society and yardstick that can be used to access the development of that society or country. Education serves as the bedrock of every society and a tool for nation building. Education is indispensable and an inevitable instrument for social and economic mobility at the personal level and an essential instrument for the transformation of society at the national level. Thus, educated individuals are seen to be a crucial catalyst for any economy through driving technological diffusion and utilization, among others (Osabuohien \& Efobi, 2012). Science and technology are required and relevant to national development and their impact on the totality of the nation cannot be overemphasized. Education in Nigeria is nationally conceptualized not just simply as the medium for cultural transmission but as the main vehicle for accelerating individual, community and national development (Kazeem \& Ige, 2010). In addition, Amosa (2016) stated that education connotes knowledge or skill acquired or developed through a learning process.

The use of ICT gadgets may enhance professional growth speedily and lecturers who use a computer system to work may gain quicker access to study materials through the internet. Similarly, Kpolovie and Awusaku (2016) submitted that ICT is a science of production and utilization of computer equipment, subsystems, software and firmware for automatic analysis, acquisition, storage, manipulation, management, movement, transformation, control, display, interchange, transmission and retrieval of data, quantitative and qualitative information most appropriate to meet human need. The use of the internet to access journals, periodicals, magazines, inaugural lectures, conference papers and so on may help lecturers to grow fast on the job (Effiong \& Effanga, 2018). Furthermore, Abdulrahman and Soetan (2017) opined that ICT is the use of scientific tools and techniques for developing, documenting and communicating information for solving problems or providing needed services in various areas of human endeavour.

Curriculum happens within the school system; it is, therefore, imperative to include indigenous knowledge into the school curricula to ensure that local/indigenous technologies are improved upon as to bring about modernization of society. Knowledgebased society of the local embedded knowledge and innovation is considered as the core competence of the curriculum of the region. In rural areas, maybe it is not suitable to adopt the high-tech or other industrial cluster development strategy as in urban areas because of the barrier of 'organizational thinness'. However, the learner's environment has their local resources, especially the intangible asset, such as cultural resources and local knowledge, and language. Besides absorbing the external knowledge, exploiting the local knowledge will also enrich the knowledge network of the learners because it is related to the environment of the learner. Moreover, because indigenous knowledge was generated from the local wisdom and culture, it fits the local situation natively.

Technology can be used to offer anticipated results with a little flaw or flawless, steady, reliable and interactivity in learning (Amosa, Ogunlade, Obielodan, \& Nasiru, 2017). Technology is the application of science. It is the making, usage and knowledge of equipment, devices, machines, techniques, crafts, systems or methods of organization in order to find solutions to a problem or perform certain roles/ functions. It could refer to the collection of tools, techniques, crafts, systems in order to solve a problem or serve some purpose (Akinbote, 2007).

Technology as the word stands is from a Greek word which means art, skills, and craft. It could apply generally to things or especially to areas like agriculture, medicine, information, construction, and basic technology. It is in this recognition of the essence attached to technology education that the federal government of Nigeria introduced a program named Universal Basic Education (UBE) to enable the acquisition of basic technology education by all Nigerians in school. According to Merriam (2010), basic technology is defined as the lowest technological skills, knowledge, aptitude which a person is taught and expected to acquire. The basic technology equips learners to present realities on how to use indigenous available resources to make products to meet up the challenge and serve purposes (Theodore, 2011).

Indigenous knowledge is the local knowledge that is unique to a culture or society. Other names for it include: 'local knowledge', 'folk knowledge', 'people's knowledge, 'traditional wisdom' or 'traditional science'. This knowledge is passed from generation to generation, usually by word of mouth and cultural values (Kube \& Nakashima 2009). 
Indigenous teaching involves making students think comprehensively and facilitating their awareness of the higher levels of content in relation to the cultural background of the learners. Indigenous Education especially focuses on teaching indigenous knowledge, models, methods, and content within

formal or non-formal educational systems. The growing recognition and the use of indigenous methods can be a response to the erosion and loss of indigenous knowledge through the process of colonialism, globalization, and modernity. Indigenous communities are able to "reclaim and revalue their languages and (traditions), and in so doing, improve the educational success of indigenous students", thus ensuring their survival as a culture (An Ecology of Indigenous Education, 2015). An An indigenous instructional resource is a teacher-based resource that is based on the culture, indigenous knowledge system and practices, and indigenous learning system of the learners and community. It is believed that this will lead students to be more participative in class since they will have the opportunity to express ideas using resources within their locality.

Utilization is the level at which the available indigenous instructional resources are used by teachers to teach basic technology in Kwara state. Utilization of resources according to Chakraborty, Islam, Bari, and Akhter (2011) is a complex behavioral phenomenon; however, it is always related to the availability and quality of such resources or services as the case may be. Utilization of tools by teachers for instructional purposes enables them to access information through increased productivity and reduced stress. Horny (2004) explains utilization to make use of available resources at the individual's disposal. According to Olagunju (2008), the utilization of indigenous instructional resources in teaching is a better way of achieving teaching objectives. When real objects or their representatives are used in teaching, students see, touch and interact with these materials. Technology offers the opportunity for access to up-to-date research reports and knowledge globally which can be accessed through proper utilization of different search engines (Nwokedi \& Nwokedi, 2017). Interactions with learning materials will help the students not to forget what they have learned easily. Olagunju and Abiona (2008) explained that the process of managing organizing resources is resource utilization.

National Policy on Education (FRN 2013), posited that basic science and technology at upper basic level are geared towards " the laying of a sound foundation for scientific, reflective and critical thinking, by providing the learner with opportunities like; development of motor skills that will allow him to perform effectively in the society within his limited capacity and providing basic instrument for further achievements, educationally together with preparation of trades and crafts of society. Science and technology have made a significant impact on man's life and society. Technology has become major factor of socioeconomic development, that their absence in life cannot be contemplated. Additionally, science and technology develops nation manpower in critical areas as; agriculture, engineering, architecture, medicine, and other science and technology professions. The importance of science and technology cuts across all conceivable areas of life. For instance, the ability of man to produce high-quality goods and services has improved exponentially. Edge cutting vaccines, drugs, sophisticated equipment and instrument have been made to help diagnose and treat different kinds of diseases thereby increasing life expectancy.

Basic science technology is the least of knowledge, skills, value which a person or learner gains from the observation and experimentation of the natural and physical factors of their environment. Bajah (2007) stated that science and technology have the utmost impact on the man from the great efforts provided by the knowledge and skills gained for the enhancement of man and his society.

Gender is the condition of being male or female. Gender implies the psychological, behavioural, social and cultural aspects of being male or female (i.e., masculinity or femininity) (American Psychological Association, 2012). Rajasekhar, Veena, and Kumar (2018) reported that there were significant differences in preferences in the use of search engines based on gender. Kpolavie \& Nwosaku, (2016) and Adekunle (2017) reported that there were no differences in attitude towards search engines based on gender. Abdulazeez (2014) opined that gender issues had been associated with the ability, skill, and competence of teachers and students to use indigenous instructional resources but without any definite conclusion. A vast number of studies have been carried out to determine if gender difference can serve as a factor in the integration and utilization of indigenous instructional resources for teaching purposes. 


\section{Statement of the problem}

Inadequate resources will surely affect the smooth teaching and learning process in all schools. Academic performance of students depends to a large extent on the indigenous resources they are exposed to but, when they are lacking in schools, students face a lot of problems. In schools across the world, students find themselves at an inherent disadvantage because their classes are not taught in their native language (Bradley, 2014). Indigenous language instruction is crucial to optimize a student's success, for many reasons. Fakomogbon (2004) opined that the lack of instructional resources and inappropriate utilization could contribute to the poor performance of students. If students are being taught in their indigenous language, they tend to understand better, more so; if indigenous instructional resources and this research employed the utilization of indigenous instructional resources in Kwara State, the need is to determine if they are available and being effectively utilized by the teachers.

\section{Research questions}

The study provided answers to the following question:

1. What types of indigenous instructional resources are available for basic technology in Upper Basic schools in Kwara State?

2. How do teachers utilize indigenous instructional resources in upper basic school in Kwara State?

3. How does gender influence the use of indigenous instructional resources?

\section{Research Hypothesis}

Ho1: there is no significant difference between male and female secondary school teachers utilization of indigenous instructional resources for teaching basic technology in Kwara State.

\section{Methodology}

This chapter presents the method and procedures that were employed in the process of collecting necessary and useful data for this research. It entails research design, sample and sampling techniques, and research instrument.

\section{Research Design}

The survey method was adopted, which allows the researcher to collect data from the sample of a relatively large population in a relatively short period of time. Data was collected using a researcher-design questionnaire to gather the necessary information which inference was drawn from.

\section{Sample and Sampling Techniques}

The population of this study involves teachers of basic technology in secondary schools in Kwara State, while the targets are all basic technology teachers in upper basic schools in Kwara State. The sample of this study was selected using simple random sampling techniques. 312 respondents were involved.

\section{Research Instrument}

The Questionnaire was used for data collection. The questionnaire comprises of four (3) section. Section A contains demographic information of the gender, respondents' age and qualification, section $B$ contains the list of available indigenous resources for teaching basic technology in secondary schools in Kwara State, the response options are; available (A), not available (NA).

Section C contains the utilization of indigenous instructional resources in secondary schools in Kwara State and the evaluation of learners, The response options were; SA-strongly agree, A- agree, D- disagree, and SD- strongly disagree.

\section{Data Analysis Technique}

The data collected through the questionnaire were analyzed using descriptive statistics including frequency and percentage table. Data was also coded and analyzed using the statistical packages for social science (SPSS). The hypothesis was tested using an independent t-test. 


\section{Data Analysis And Results}

This chapter presents the analysis of the assessment of the utilization of indigenous instructional resources for teaching basic technology in secondary schools in Kwara State, the interpretation of the data through the analysis of the questionnaire items after administration was done. The chapter presents the description of the research subjects, statistical analysis and results based on research questions and research hypotheses stated earlier in chapter one. The demographic information of the respondents and the results of the analysis are also presented in Tables and figures.

Table 1: Population of Respondents for the Study

\begin{tabular}{|c|c|c|}
\hline Estimated Population & Returned & Return Rate \\
\hline 350 & 312 & $89.1 \%$ \\
\hline
\end{tabular}

Table 2: Respondents Data based on Gender

\begin{tabular}{|c|c|c|c|}
\hline Gender & Frequency & Percent & Cumulative Percent \\
\hline Male & 189 & 60.6 & 60.6 \\
\hline Female & 123 & 39.4 & 100.0 \\
\hline Total & 312 & 100.0 & \\
\hline
\end{tabular}

Figure 1: Pie Chart on Respondents' Gender

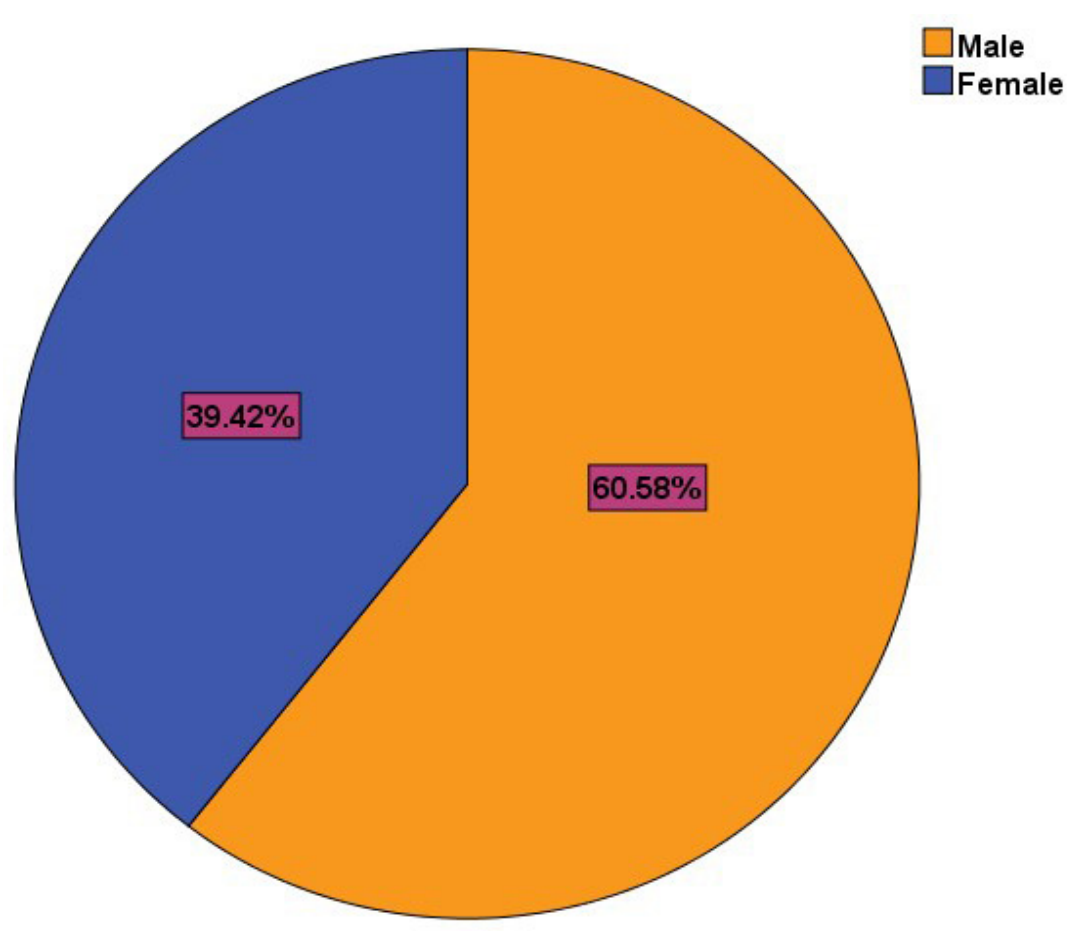

As displayed in table 2, the respondents comprised of 63 males and 41 females.

This was further shown in figure 1. 
Table 3: Respondents Data based on Age

\begin{tabular}{|c|c|c|c|}
\hline Age & Frequency & Percent & Cumulative Percent \\
\hline $21-25$ Years & 33 & 10.6 & 10.6 \\
\hline $26-30$ Years & 123 & 39.4 & 50.0 \\
\hline 31 Years and Above & 156 & 50.0 & 100.0 \\
\hline Total & 312 & 100.0 & \\
\hline
\end{tabular}

Figure 2: Pie Chart on Respondents' Age

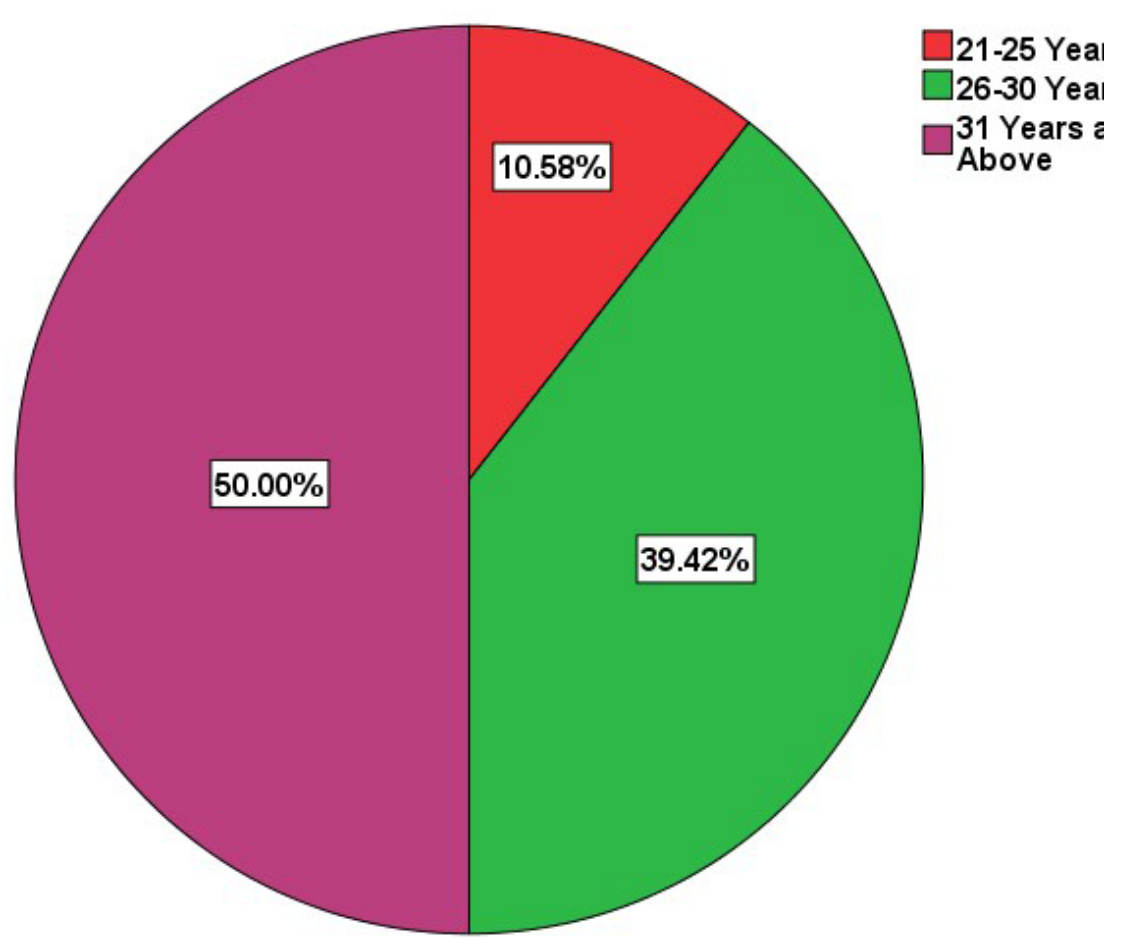

As displayed in table $3,10.6 \%$ of the respondents are within the age of $21-25$ years old, $39.4 \%$ are within the age range of $26-30$ years while $50 \%$ are within the age range of 31 years and above.

This was further shown in figure 2.

Table 4: Respondents Data based on Qualification

\begin{tabular}{|c|c|c|c|}
\hline Qualifications & Frequency & Percent & Cumulative Percent \\
\hline OND & 9 & 2.9 & 2.9 \\
\hline NCE & 66 & 21.2 & 24.0 \\
\hline B.Ed. & 75 & 24.0 & 48.1 \\
\hline B.Sc. & 120 & 38.5 & 86.5 \\
\hline PGDE & 12 & 3.8 & 90.4 \\
\hline M.Ed & 27 & 8.7 & 99.0 \\
\hline M.Sc & 3 & 1.0 & 100.0 \\
\hline Total & 104 & 100.0 & \\
\hline
\end{tabular}


Figure 3: Pie Chart on Respondents' Highest Qualification

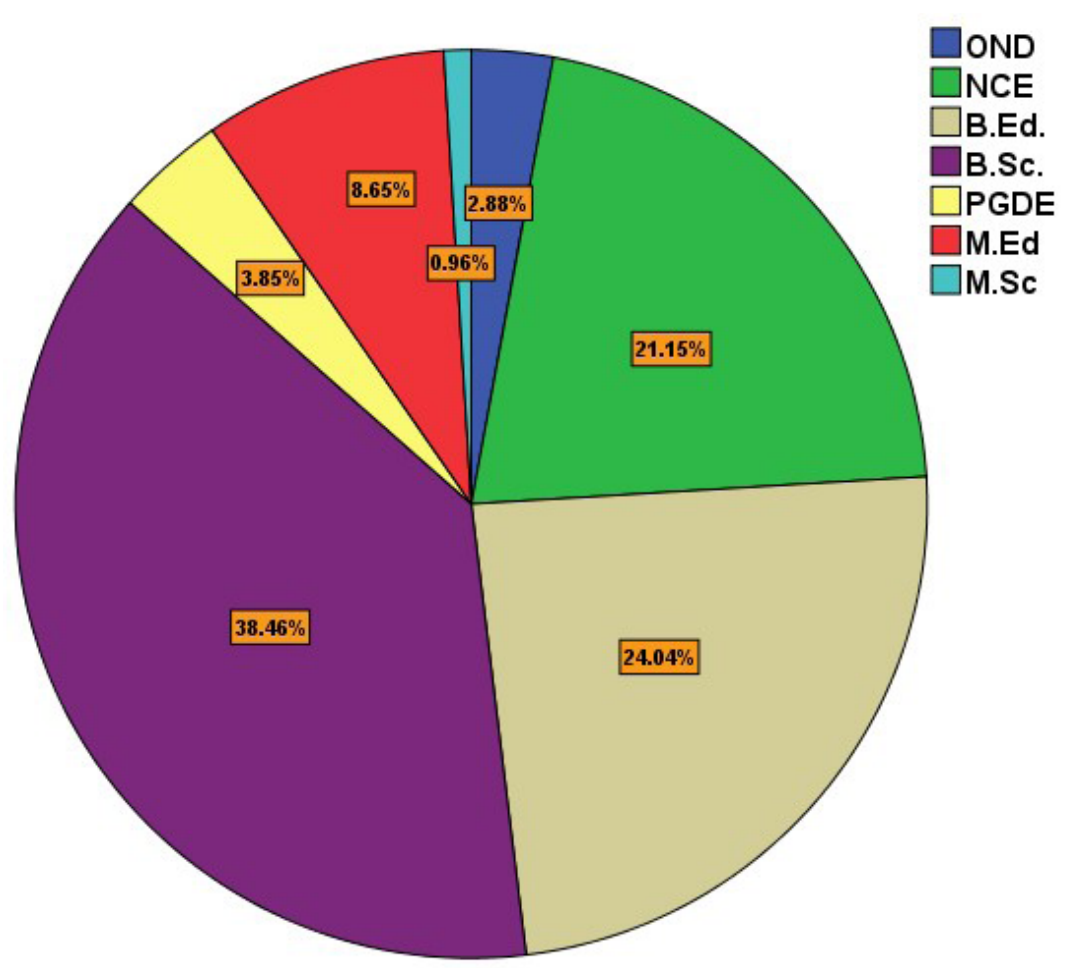

The Respondents' distribution based on their highest qualification are shown in table 4 . It indicated that majority (24\%) of the respondents have B.Ed as highest qualification, $38.5 \%$ of the respondents have B.Sc as their highest qualification, $21.2 \%$ of the respondents have NCE as their highest qualification. Others followed suit as shown in table 2 and figure 3.

\section{Results}

Research Question One: What kind of indigenous instructional resources are available for basic technology in secondary schools in Kwara State?

Table 5: Indigenous Instructional Resources Available For Basic Technology

\begin{tabular}{|c|l|c|c|}
\hline \multirow{2}{*}{ S/N } & & \multicolumn{2}{|c|}{ AVAILABILITY } \\
\cline { 3 - 4 } & & \multicolumn{2}{c|}{ A } \\
\hline 1 & Timber & $288(92.3 \%)$ & $24(7.7 \%)$ \\
\hline 2 & Ceramics & $192(61.5 \%)$ & $120(38.5 \%)$ \\
\hline 3 & Talking drum & $219(70.2 \%)$ & $93(29.8 \%)$ \\
\hline 4 & Coal pot & $219(70.2 \%)$ & $93(29.8 \%)$ \\
\hline 5 & Artifacts & $102(32.7 \%)$ & $210(67.3 \%)$ \\
\hline 6 & Brass cup & $129(41.3 \%)$ & $183(58.7 \%)$ \\
\hline 7 & Wooden basket & $192(61.5 \%)$ & $120(38.5 \%)$ \\
\hline 8 & Bamboo & $219(70.2 \%)$ & $93(29.8 \%)$ \\
\hline 9 & Kerosene stove & $219(70.2 \%)$ & $93(29.8 \%)$ \\
\hline 10 & Clay pot & $243(77.9 \%)$ & $69(22.1 \%)$ \\
\hline
\end{tabular}


The kind of indigenous instructional resources that were available for basic technology in secondary schools in Kwara State was investigated and the result was presented in table 5 . It indicated that $92.3 \%$ of the respondents had timber as indigenous instructional resources, $61.5 \%$ respondents had ceramics in teaching basic technology $70.2 \%$ respondents had talking drum, coal pot, bamboo and kerosene stove, $64 \%$ of respondents had weave basket and $77.9 \%$ respondents had clay pot. Thus, the majority of the respondents had timber, ceramics, talking drum, coal pot, bamboo and kerosene stove, weave basket and clay pot.

Research Question Two: What are the ways in which indigenous instructional resources in secondary schools in Kwara State are being utilized?

Table 6: Utilization of Indigenous Instructional Resources

\begin{tabular}{|c|l|r|r|}
\hline $\mathbf{S} / \mathbf{N}$ & \multicolumn{1}{|c|}{ ITEMS } & MEAN & STD. DEV \\
\hline $\mathbf{1}$ & Planks which are gotten from timber are used to teach wood processing. & 3.11 & .85 \\
\hline $\mathbf{2}$ & $\begin{array}{l}\text { I use Ceramics which are products of non-metallic rocks and minerals to teach } \\
\text { ceramics and metal. }\end{array}$ & 3.50 & .73 \\
\hline $\mathbf{3}$ & I use Talking drum which is made with wood to teach wood processing. & 3.02 & .89 \\
\hline $\mathbf{4}$ & $\begin{array}{l}\text { I make use of Coal pot which is carved from metal for means of instructional mate- } \\
\text { rial for teaching metal. }\end{array}$ & 3.03 & .90 \\
\hline $\mathbf{5}$ & $\begin{array}{l}\text { I use Artefacts which are carved from wood and metal to teach metal and wooden } \\
\text { materials. }\end{array}$ & 3.13 & 1.01 \\
\hline $\mathbf{6}$ & $\begin{array}{l}\text { Brass cup is an instructional material made from brass which are used in teaching } \\
\text { natural resources. }\end{array}$ & 2.78 & .90 \\
\hline $\mathbf{7}$ & $\begin{array}{l}\text { Wooden tricycle is an instructional material gotten from wood and metal which i } \\
\text { use in teaching motion. }\end{array}$ & 2.69 & .92 \\
\hline $\mathbf{8}$ & $\begin{array}{l}\text { Various furniture which is made using bamboo are used for instructional purpose } \\
\text { in the classroom. }\end{array}$ & 2.89 & 1.00 \\
\hline $\mathbf{9}$ & $\begin{array}{l}\text { Kerosene stove which was made using metallic material is utilized in teaching } \\
\text { metallic product }\end{array}$ & $\begin{array}{l}\text { Clay pot, clay cup are examples of clay products and can be used in teaching basic } \\
\text { technology concepts. }\end{array}$ & 3.00 \\
\hline & Grand Mean & 3.14 & 1.00 \\
\hline
\end{tabular}

How indigenous instructional resources in upper basic school in Kwara State are being utilized was investigated and the result is presented in table 6. It revealed that most of the respondents used planks which are gotten from timber to teach wood processing with mean of 3.11. Also, Ceramics which are products of non-metallic rocks and minerals are used to teach ceramics and metal. Basic technology teachers use talking drum which is made with wood to teach wood processing. Others followed suit as shown in table 6. With grand mean of 3.14 which was greater than the bench mark of 2.50, the available indigenous instructional resources are being utilized by basic technology teachers in Kwara State. 
Research Question Three: What is the Influence of gender in using indigenous instructional resources?

Table 7: Gender Difference in Using Indigenous Instructional Resources

\begin{tabular}{|c|c|c|c|}
\hline Gender & $\mathbf{N}$ & Mean & Mean Gain \\
\hline Male & 189 & 3.12 & \multirow{2}{*}{0.05} \\
\hline Female & 123 & 3.17 & \\
\hline Total & 312 & & \\
\hline
\end{tabular}

The influence of gender on the use of indigenous instructional resources was presented in table 8.

The mean score on male teachers' use of indigenous instructional resources was 3.12 while the mean score on female teachers' use of indigenous instructional resources was 3.17. The mean difference was 0.05 indicated that female basic technology teachers use indigenous instructional resources more than their male counterparts.

\section{Research Hypothesis}

Ho1: there is no significant difference between male and female teacher utilization of indigenous instructional resources for teaching basic technology.

Table 8: Test analysis on male and female undegraduates' perception

\begin{tabular}{|c|c|c|c|c|c|c|c|}
\hline Gender & $\mathbf{N}$ & Mean & $\begin{array}{c}\text { Std. } \\
\text { Deviation }\end{array}$ & Df & T & $\begin{array}{c}\text { Sig. } \\
\text { (2-tailed) }\end{array}$ & Remarks \\
\hline Male & 189 & 3.1175 & .9335 & & & & \\
\hline Female & 123 & 3.1683 & 1.12282 & 310 & -0.250 & 0.803 & Accepted \\
\hline Total & 312 & & & & & & \\
\hline
\end{tabular}

Table 8 indicates that $\mathrm{t}(310)=-0.25, \mathrm{p}=0.80$. This means that the stated null hypothesis was not rejected. This was a result of the t-value of 0.25 resulting in 0.80 significance value which was greater than 0.05 alpha value. It was deduced that there was no significant difference between male and female teacher utilization of indigenous instructional resources for teaching basic technology.

\section{Discussions}

This study investigated the assessment of the utilization of indigenous instructional resources for teaching basic technology in upper basic schools in Kwara State. The finding revealed that the available indigenous instructional resources for teaching basic technology in upper basic schools in Kwara State are being utilized. The utilization of indigenous instructional resources is based on the fact that certain indigenous instructional resources are available in various upper basic schools in Kwara State. This finding is in line with the assertion of Brain (2011) that lessons taught with the guide of indigenous instructional material arouse learner's interest to understand what is been taught. They are imperative in exciting the premium and creative energy of the learners. They make conceptual thoughts (abstract ideas) more concrete for appreciation. Through this, instructional resources give the comprehension of the subject lesson. Sandberg (2018) revealed that depending on what men and women like to discuss about on social media, their platform of choice may also vary.

This study is also in line with the assertion of Okeke (2010) that instructional materials empower educators to accomplish applied thinking, diminish verbalization, blend the subject, excite self-action and make enthusiasm for a few themes. These help the learners in retention, the advancement of sharp perception and aide imaginative reasoning. Blended learning offers a wider opportunity to develop education to be more enhanced and productive to provide both lecturers and students with the utilization of the right learning resources, independent learning and appropriate teaching to the students at the appropriate time (Kadek, Putu, 
Herman, \& Priyanto, 2018). To achieve functional education goals, the utilization and effective use of indigenous instructional material are necessary for schools. Curzon (2017) points out that using indigenous instructional materials in basic technology classrooms widen the channel of communication between teachers and their students.

The finding established that female basic technology teachers use indigenous instructional resources more than their male counterparts, this is not in line with Litt (2013) indicating that male teachers seem to report a higher level of using indigenous instructional resources than female teachers. Van Deursen (2012) reported that males perform better than females on indigenous instructional resources assessments. Research by Meelissen (2005) also showed that female seems to have a lower self-efficacy compared to male especially in the use of more complicated indigenous instructional resources. There are few lectures in some of the institutions that are ready to adopt the practical areas such as micro-teaching sessions that help students exercise, in creating, production and utilization of instructional materials (Ann \& Nsofor,2014).

The finding of this study indicates that there is no significant difference between a male and female teachers in the utilization of indigenous instructional resources. Ahmad (2015) revealed that there is no significant difference between male and female based on their utilization of electronic information resources for learning. This study also indicates that the unawareness of the importance of using indigenous instructional resources, sub-standard resources, as well as environmental factors affect the durability of indigenous instructional resources. It has been analyzed that academic performance averages of the female students have turned out to be higher than the academic performance averages of the male students in a blended learning environment (Demirkolb \& Kazua, 2014).

\section{Conclusion}

The field of education has not been left out in the adoption of indigenous instructional resources. The real purpose behind indigenous instructional resources use in the classroom instructing is to appeal to all senses of learners in the learning circumstances. The sensory experience could be gustatory (taste), kinesthetic (touch), auditory (hearing), olfactory (smell) or optical (seeing). Adequacy is more noteworthy in the teaching and learning process when more than one of these senses is stimulated. Lessons taught with the guide of indigenous instructional material arouse learner's interest to understand what is been taught. A river that forgets its origin will dry up in due time, so also any educational settings that do away with its indigenous resources could go into extinction as regards to the use of learning materials.

\section{Recommendations}

Based on the findings and conclusion of this study, the following recommendations were made:

1. Given that upper basic education is part of basic education, the government should ensure that indigenous instructional resources are adequate in all categories of upper basic school.

2. The education body should create awareness programs for teachers to cater for the importance of utilizing indigenous instructional resources.

3. There is a need to evolve policy actions that will increase access to indigenous instructional resources and actions to improve its quality.

4. The government should allocate funds according to the needs of each upper basic school to cater to environmental factors limiting the durability of utilizing indigenous instructional resources. 


\section{References}

» Abdulrahman, M. R., \& Soetan, A. K. (2017). Lecturers perceived ease of use mobile devices for teaching undergraduates Kwara state. Conference Proceedings Association for Innovative for Innovative Technology in Education (AITIE 2017) (pp. 151-162). Ilorin: Association for Innovative Technology in Education.

»Abraham, I. B. (2008). Universal basic education for national survival. The olace of basic technology education in JSS. Benue State University journal of, Education, 1(4) 161-171.

»Ajelabi, A. (2015). Essentials of Educational technology Lagos: Raytel Communication Itd

» Akinbote, O. (2007). Problems for Teacher Education for Primary Schools in Nigeria: Beyond Curriculum Design and Implementation. Essay in education, 22

» Akinpelu, J. A. (2011). Philosophy of Education. London: Macmillian.

»Akinsolu, A. O.(2012) Resource utilization and internal efficiency in Nigeria secondary schools: Implications for socio problems of education. International Journal of Sociology and Anthropology 12(3), 156-178. Retrieved from http://www.academicjournals.org/ijsa.

»Amosa, A. A. (2016). Community resources and classroom instruction. In M. O. Yusuf, \& S. A. Onasanya, Critical Issue in Educational Technology (pp. 105-110). Ilorin: Department of Educational Technology, University of llorin.

»Amosa, A. A., Ogunlade, O. O., Obielodan, O. O., \& Nasiru, A. A. (2017). Students' learning autonomy and facilitating conditions on the utilization of blended learning among pre-service teachers in University of Ilorin. conference proceedings Association for Innovative Technology in Education (AITIE 2017) (pp. 67-74). Ilorin: Association for Innovative Technology in Education Instructional Resources for Effective Teaching. Lagos: Oyasin Press.

\Anabe, P. P. (2010). Instructional Resources for Effective Teaching. Lagos: Oyasin Press.

»Ann, E. U., \& Nsofor, C. C. (2014). Modern Trends in The Use of Educational Technology in The Classroom. International Journal of Education Learning and Development, 73-77. Retrieved from http://www. eajournals.org/wp-content/uploads/Modern-Trends-In-The-Use-Of-Educational-Technology-In-TheClassroom.pdf

Babalola, B. N. (2010). Technology education examination overview in Nigeria. Nigeria Vocational Teacher Education Today, 1(20), 96-100.

Bajah M, C. (2007). An evaluation of vocational teachers education in Nigeria. Uyo Tima Publishers.

Bates P, Chiba, M, Kube, S. and Nakashima, D. (2019). Learning and knowing in indigenous societies of Today, UNESCO, Paris

Bradley, C. M (2014). Higher education research and development: students skills and the Bradley agender Brain, K. C. (2011). Technology. New York: McGraw Hill Book Co. Inc.

Dike S, (2014). Opening Remarks Presented at the Train-the-trainers Workshop on the use of the Revised 9-year Basic Education Curriculum held at Rockview Hotel, Abuja Nigeria, 5-9th August, 2014, Curriculum: Primary and junior Secondary School Levels. Lagos: NERDC Press.

Effiong, U. O. \& Effanga, E. M. (2018). Professional development and lecturers' job effectiveness in universities in South-South Geo-Political Zone of Nigeria. Journal of Education and Practice, 9(12), 123-128. Fafunwa, B. E. (2011) History of education in Nigeria, London, George, Allen and unioun Itd

» Fakomogbon, M. A: Ibrahim, A. I. \& Gegele, W. B. (2007). An introduction to vocational method. Ilorin: Onigba. Printing production.

Federal republic of Nigeria (2013). National policy on education. (4th ed), Lagos, NERDC Federal Government Printers

FME (2012). The Revised 9-year Basic Education Curriculum: Basic Science and technology Lagos: NERDC press.

» Gregory. A Cajete. An ecology of indigenous education (2015): Retrieved from https//doi. org/10.1177/1742715015610412 Grenier. L. ( 2011) Working with Indigenous Knowledge: a Guide for Researchers, IDRC, Canada Harris, B. N. (2011). Introduction to educational evaluation process. America: Sage Kaduna Harris, douglas N. \& Sass, Tim R, (2011). Teacher training, teacher quality and student achievement: journal of public economics, Elsevier, vol. 95(7-8) (p 798-812)

» Harris, J. B, \& Grandgenet, N. (2010). Correlates among teachers' anxieties, demographics, and 
telecomputing activity. Journal of Research on Computing in Education, 28(3). 300-317

IFAD (2003) Indigenous peoples and Sustainable Development, Roundtable Discussion Paper for the Twenty-fifth Anniversary Session of IFAD'S Governing council.

Kazeem, K. \&lge, O. (2010). Redressing the growing concern of the education sector in Nigeria. Edo journal of counselling, 3(1), 34-43.

» Kpolovie, P. J., \& Awusaku, O. K. (2016). ICT adoption attitudes of lecturers. European Centre for Research Training and Development, 4 (5), 9-56.

Nwokedi, V. C. \& Nwokedi, G. I. (2017). Assessment on use of search engines by lecturers in the Faculty of Medical Sciences, university of Jos, Nigeria. Journal of Applied Information Science and Technology, 10(2), 23-32.

» Okeke, B. N. (2010). Effect of lecture method in teaching of basic technology I secondary school in Nsukka education zone. Unpublished M.ed Project, University of Port-Harcourt.

Onasanya, S. A, Adegbija, M. V (2007). Practical Handbook on Instructional (Second Edition) Ilorin: Graphicom Publishers.

Onasanya, S. A, Adegbija, M. V, Olumorin C. O. \& Daramola, F. O. (2008). Assessment of Teachers' Competence in Instructional Media Technology. Use in junior secondary school in Kwara State in Education Reforms in Nigeria: past, present and future (2008). Adebayo, R. L; Shehu, A. J, Olurundare, S. A \& ljaiya, NYS. (Eds), 259-270.

Onasanya, S. A. (2004). Selection and Utilization of instructional media for effective practice teaching. Institute journal of Studies in Education, 2(1), 128-133.

Onyejemiezie, D. A. (2013) Eductional Technology in Nigeria Education. Onitsha: Summer Eduction Publishers.

»Sandberg, S. (2018). Gender and Social Networking. The world's gone social. And women are more social than men. Retrieved from https://www.wikigender.org/wiki /gender-and-social -networking/ Theodore, P. N. (2011). Levels of acquisition of science process skills among SSI biology students in Anambra State. Awka: Agbuonu Publishers. Universal Basic Education Board (UBEB, 2008). Problem of UBE in Nigeria. Abuja: Government Press.

Wikipedia/org/wiki/educational technology. Retrieved 07/29/2010 Pp. 1-4.

World Bank (2004) Indigenous knowledge: local pathways to global development, Africa Regional Office, World Bank. 